\title{
Fairy Tales as Manuals of Becoming a Good Girl: A Study in the Politics of Gender
}

\author{
Farhana Rea Deeba* \\ Dept. of English Language and Literature, Jatiya Kabi Kazi Nazrul Islam University, Mymensingh, Bangladesh \\ *Corresponding Author: Farhana Rea Deeba, Dept. of English Language and Literature, Jatiya Kabi \\ Kazi Nazrul Islam University, Mymensingh, Bangladesh
}

\begin{abstract}
Fairy Tales are common items that most of the children are open to. In fairy tales, many stories are female-character centered which contain teachings and ideas a girl receives from these appealing stories and carries all through her life consciously or unconsciously. The psychological development of that child coheres with her physical development and at the end, with her self-evaluation process. The perception of her own self and the surroundings is shaped and conditioned by the stories she has heard or read repeatedly in her childhood. It can be noticed that the stereotypical images of the female characters define her personal and social roles for future life. Therefore, gender studies or feminist literary criticism can be criticallyused as a major theoretical tool to examine this aspect of the fairy tales. This paper explores issues like how the idea and process of becoming is given emphasis in the stories.
\end{abstract}

Keywords: Fairy Tales, angel and monster, definition of beauty.

The fortunate little princess was to grow up the fairest woman in the world; to have a temper sweet as an angel; to be perfectly graceful and gracious; to sing like a nightingale; to dance like a leaf on a tree; and to possess every accomplishment under the sun.

...The Sleeping Beauty in The Wood ${ }^{1}$

Ideology is "the set of attitudes, values and perceptions through which we come to understand and relate to the given world;" " it is the core to human consciousness and thus fundamental issue for human existence. The construction of ideology of a civilised wo/man works hand in hand with the influence of hegemony. Antonio Grumsci says that the function of hegemony (control of ideas which manipulates social consciousness as economic and physical force alone was not enough to ensure control $^{3}$ ) is to transform ideology into culture, into a "world view" that is seen as "normal" and "natural" by everyone from the controlling class to the subordinate classes. ${ }^{4}$ And, for this reason, childhood seems to be the phase of life, where hegemony can function in its best possible way in the process of framing the ideology, which will control the person with his/her perception of the world for the rest of the life. Most of the children grow up with the attractive and compelling fairy tales. This fact has an immense psychological value,since nothing is stronger than the teachings we had in our childhood, and the adult mind does not easily agree to accept the new ideas replacing the old ones.

The process of image-fixation starts with offering some female characters, in the fairy tales for children, which could explicitly be divided in two categories. One consists of the good, angelic and admirablecharacters - beautiful, innocent, helpless, perseverant, sacrificing group of queen-princess, mother-daughter; and another group is made of all the evil, aggressive, angry, wicked but powerful, strong and intelligent stepmothers or witches. For girls these are the only two options left to choose between: either you become the angel, the ideal woman who is passive, docile and above all selfless creature, or,on the other hand, youbecome the monster, who refuses to be selfless, acts on her own

\footnotetext{
${ }^{1} \mathrm{http} / / / \mathrm{www}$. tonightsbedtimestory.com/the-sleeping-beauty-in-the-wood/

${ }^{2}$ Rupert Woodfin and Oscar Zarate, IntroducingMarxism, op. cit., p. 120.

${ }^{3}$ Ibid., p. 121.

${ }^{4}$ qtd. in ibid., p. 124.
} 
initiative, who has a story to tell - in short, a woman who rejects the submissive role patriarchy has reserved for her". The stepmother of Snow White was "a beautiful woman, but proud and haughty, and she could not bear that anyone else should surpass her in beauty... And envy and pride grew higher and higher in her heart like a weed, so that she had no peace day or night." . She with beauty and extraordinary magical power,without doing anything else, involves all her time and energy in making a plan to kill a helpless, innocent baby girl. Or, there is the witch from Sleeping Beauty, who feels neglected and insulted as a result of being aged and thus unwanted, tries to demonstrate her still existing power with a wicked curse. The innocent stories thus become a tool to teach the existing patriarchal ideology by projecting antithetical images of women: the idealized projections of men's desires (the Madonna, the Muse of the arts, Dante's Beatrice, the pure and innocent virgin, the "Angel in the House") or the demonic projections of men's sexual resentments and terrors (Eve and Pandora as the sources of all evil, destructive sensual temptresses such as Delilah and Circe, the malign witch, the castrating mother). ${ }^{7}$ The male or female child gathers their first knowledge about their own race (the human race) from these stories, and they learn how they should behave to earn love and praise now and afterwards.

Cindrella, Rapunzel, Sleeping Beauty, Snow White and Seven Dwarfs, Beauty and the Beast, The Little Mermaid, Rumplestiltskin, The Little Red Riding Hood are most popular fairy tales which are female-character centred. These stories idealize limited gender roles and qualities. The most desired feminine quality is being beautiful which is marked by the skin complexion, weight, colour of the eyes, length of the hair and age; as Snow White's mother "thought to herself, would that I had a child as white as snow, with lips as red as blood, and hair as black as the wood of the window-frame. ${ }^{8}$ Or like Rapunzel who had magnificent long hair, fine as spun gold, and when she heard the voice of the enchantress she unfastened her braided tresses, wound them round one of the hooks of the window above, and then the hair fell twenty ells down. ${ }^{9}$

The fixed marks of beauty in appearance get intensified while being added with some human traits like submission, obedience, humbleness, patience and sacrifice. And the common theme that appears to be in those is a story of a destitute womanwaiting to be rescued by apowerful "prince" and has to go a long way of suffering in order to find him. The reward of that "right-minded" woman like Cindrella, who is a young daughter, of rare goodness and sweetness of temper, which she takesfrom her mother, who isthe best creature in the world ${ }^{10}$, is the successful marriage with the 'right bridegroom'. So, it becomes natural for the Little Mermaid, a character who actually gives up hervoiceto get a man. ${ }^{11}$ The stories end ensuring a life "happily ever after" with a marriage which promotes the idea that only a wealthy man, the prince, can bring the confirmation of happiness in the life of a woman. As there is reward, there is also punishment for the girls who will step off the path. In "Little Red Riding Hood" confrontation with the danger, in the shape of wolf,comesas a result of not paying heed to the social warnings.

In this scenario, women are rivals as Cindrella and her step-sisters, and they are set in a competition against each other over a man as no other means of survival is allowed for them. The stories stress the importance of marriage as the only possible means of reaching the happiness where the economic or social status of a woman is visibly related with whom she is married. All of these fairy tales suggest a common motivation and goal where the prince appears to be the essence, the key of survival to the helpless and passive girls where she is nearly an object of possession. For this reason, in "Beauty and the Beast" Belle's father can gamble her away at cards. The person-less heroine, having no other way, thus takes part in the competition of marrying the "prince" and, being the "fairest among all", wins the race.They accept the "patriarchal ideology (that is, the conscious and unconscious presuppositions about male superiority), and so are conditioned to derogate their own sex and to cooperate in their own subordination." ${ }^{12}$ And what isthe first thing that culture tellsher about being a girl? Not that she

\footnotetext{
${ }^{5}$ TorilMoi, Sexual/textual Politics: Feminist Literary Theory, $2^{\text {nd }}$ ed., 2002, p. 57.

${ }^{6} \mathrm{https}: / /$ www.win.tue.nl/ marko/latex/exercises/day2/snowwhite2.pdf

${ }^{7}$ M. H. Abrams, A Glossary of Literary Terms, 6th ed., op. cit., p. 236.

${ }^{8}$ https://www.win.tue.nl/ marko/latex/exercises/day2/snowwhite2.pdf

${ }^{9}$ Ibid, p. 57

${ }^{10}$ Ibid, p.4

${ }^{11}$ Peggy Orenstein, Cindrella ate my Daughter: Dispatches from the front lines of the new Girlie-Girl Culture, p.2.

${ }^{12}$ M. H. Abrams, A Glossary of Literary Terms, 6th ed., Bangalore: Prism Books, 1993, p. 235.
} 
iscompetent, strong, creative, or smart but that every little girl wants - or should want - to be the Fairest of Them All ${ }^{13}$ where beauty is connected with goodness and ugliness is the sign of evil.

Nothing can be as influencing as the fairy tales that the girls read or hear in their childhood, to pursue the standard of beauty as described in the stories. From a very early age they start their struggle to gain "the feminine beauty ideal". It is a socially constructed notion that physical attractiveness is one of the important assets that a woman can possess and it is something all women should strive to achieve. ${ }^{14}$ In the story "Rumpelstiltskin" this hidden truth is described through symbols where"Most women within the early nineteenth century were not even perceived to be involved in the important events of history...Women's activities and accomplishments were overshadowed by men's and deemed irrelevant to history. This was due to the fact that women's roles were restricted to the domestic sphere... In "Rumpelstiltskin" women are controlled by men; the maid is controlled by the king - her future husband - and Rumpelstiltskin." ${ }^{" 15}$ Society offers women a suitable profession that becoming the wife and then mother. And to be successful professional women they should possess certain qualities like beauty, submissiveness, patience, endurance, softness and passivity. "Woman is the opposite, the 'other' of man: she is non-man, defective man, assigned a chiefly negative value in relation to the male first principle," 16 in a world where "all history has been made by men... a world that belongs to men...,"17 and she is without any memory of glorious former days.

This mirroring effect leads the girl child to self-mutilation and sometimes self-hatred as a result of failing, most strongly when she reaches her adolescence.Women's stripping their bodies with unhealthy and uncomfortable, restrictive clothing like bras, girdles, corsets, garter belts, etc. - was a ritualistic, radical reclaiming of the health and glory of the female body. ${ }^{18}$ To gain a certain amount of weight and fairness, that group of girls do not hesitate to take harmful medicines and drugs, in addition to it, lead an unhealthy life taking an unhealthy diet, thus having a life-long risk of suffering from different diseases like malnutrition, iron deficiency, lack of energy, low blood pressure and other acute diseases. Nowadays, in the fashion world, especially on the consumer side, where clothing that looks like it has been designed simply for reed-thin adolescent girl bodies is the norm, all females no matter their age are being socialized either consciously or unconsciously to have anxiety about their body, to see flesh as problematic. ${ }^{19}$ To fit with the given definition of beauty, with the perfect body shape and skin complexion, the girl pursues other necessary accessories like high heels, uncomfortable outfits or makeup products. The fairy tales teach us that the girls should have the perfect shape like Cindrella and if she does not then like her stepsister when"she could not get her great toe into it, for the shoe was too small; then her mother handed her a knife, and said, 'Cut the toe off, for when you are Queen you will never have to go on foot.' So the girl cut her toe off, squeezed her foot into the shoe, concealed the pain, and went down to the Prince." 20

All the struggles and pains will lead her to the ultimate goal, marriage. She will achieve, at the end, the destiny she was waiting for all through her life, becoming a perfect wife and an ideal mother. The girl, from her childhood, learns what is waiting for her if she follows the right track and, being blinded by the romantic illusions like love at first sight, the chance of meeting the prince charming or having happiness that will last forever, co-operates with the construction of traditional gender stereotypical role. Fairy Tales give definitions for both the appearance and personality, and thus create a complete image of female hood. In the pursuit of attaining the life like fairy tales, many girls forget that there might be other career options or there might be other definitions of beauty. Therefore, it is necessary to analyse the dominant cultural ideologies the characters of the Fairy Tales are subservient to and, besides, to analyse thoroughly how there remains the scope of re-reading the stories and examining whether there is any hidden intention or not, under the apparent appreciable moral teachings those are offering through the creation of binary opposite characters.

\footnotetext{
${ }^{13}$ Ibid, p.3.

${ }^{14}$ https://www.indianfolk.com/fairytales-beauty-ideal-edited/

${ }^{15} \mathrm{http}: / /$ bsuenglish.com/dlrOLD/current/issue4_rumpelstiltskin.pdf

${ }^{16}$ Terry Eagleton, Literary Theory: An Introduction, 2nd ed, Oxford: Blackwell, 1996, p. 115.

${ }^{17}$ Simone de Beauvoir, The Second Sex, Ed. and Trans. H. M Parshley, London: Jonathan Cape, 1953, p. 20.

${ }^{18}$ bell hooks, Feminism is for Everybody: Passionate Politics, Cambridge:South End Press, p. 31.

${ }^{19}$ ibid, p. 35

${ }^{20} \mathrm{http}: / /$ pinkmonkey.com/d1/library1/story012.pdf, p. 5.
} 


\section{REFERENCES}

[1] Abrams, M. H. A Glossary of Literary Terms.6th ed. Bangalore: Prism Books, 1993. Print.

[2] Beauvoir, Simone de.The Second Sex. Ed. and Trans. H. M Parshley, London: Jonathan Cape, 1953. Print.

[3] Eagleton, Terry. Literary Theory: An Introduction. 2nd ed. Oxford: Blackwell, 1996. Print. hooks, bell. Feminism is for Everybody: Passionate Politics, Cambridge: South End Press, 2000. Print.

[4] Moi, Toril. Sexual/textual Politics: Feminist Literary Theory. London and New York: Routledge, 2002. Print.

[5] Orenstein, Peggy. Cindrella ate my Daughter: Dispatches from the front lines of the new Girlie-Girl Culture.HarperCollins e-books.Accessed on 19 April 2019.Web.

[6] Woodfin, Rupert and Oscar Zarate.IntroducingMarxism. Royston: Icon Books, 2004. Print.

[7] http://www.tonightsbedtimestory.com/the-sleeping-beauty-in-the-wood/

[8] https://www.win.tue.nl/ marko/latex/exercises/day2/snowwhite2.pdf.

[9] https://www.indianfolk.com/fairytales-beauty-ideal-edited/

[10] http://bsuenglish.com/dlrOLD/current/issue4_rumpelstiltskin.pdf.

[11] http://pinkmonkey.com/d1/library1/story012.pdf.

Citation: Farhana Rea Deeba. Fairy Tales as Manuals of Becoming a Good Girl: A Study in the Politics of Gender. "International Journal on Studies in English Language and Literature (IJSELL), vol 7, no. 11, 2019, pp. 29-32. doi: http://dx.doi.org/10.20431/2347-3134.0711004.

Copyright: () 2019 Authors. This is an open-access article distributed under the terms of the Creative Commons Attribution License, which permits unrestricted use, distribution, and reproduction in any medium, provided the original author and source are credited. 